\title{
Vexing Motherhoods in Ireland and Abroad in Nuala Ní Chonchúir's Mother America
}

\author{
Aitor Ibarrola-Armendariz \\ University of Deusto, Spain
}

Copyright (c) 2018 by Aitor Ibarrola-Armendariz. This text may be archived and redistributed both in electronic form and in hard copy, provided that the author and journal are properly cited and no fee is charged for access.

\begin{abstract}
This article explores the difficulties of representing motherhood from a contemporary - and, allegedly, feminist - perspective in the collection of short stories Mother America (2012) by Irish author Nuala Ní Chonchúir. The stories in the volume include a whole typology of mothers: surrogate mothers, exiled mothers, mothers who see their child abducted and others who tattoo them for protection, all of whom need to deal with particular crises which usually change them in profound ways. Although the writer proves very brave in challenging and revising some of the myths and dominant discourses about motherhood in earlier historical periods, she also sometimes resorts to a number of clichés concerning mothers and children that may somehow endanger their qualification as conventional feminist texts. Like some of the literature on the subject, Ní Chonchúir seems rather hesitant and ambivalent about whether motherhood should be primarily conceived as a social construct or institution - or rather as something natural and innate to the female condition. In any case, Mother America offers penetrating insights into the dilemmas that frequently accompany motherhood and very rarely passes moral judgments on the (rather habitual) failures and the (much less common) triumphs of the characters.
\end{abstract}

Key Words. Mother America, short stories, motherhood, Nuala Ní Chonchúir, unusual motherhoods, betrayed wives.

Resumen. El presente artículo analiza los problemas de la representación de la maternidad desde una perspectiva contemporánea - y, supuestamente, feminista - en la colección de relatos Mother America (2012) de la autora irlandesa Nuala Ní Chonchúir. Estos relatos incluyen toda una tipología de madres diferentes: madres subrogadas, exiliadas, madres cuyos hijos son robados y otras que los tatúan para protegerlos, todas las cuales se ven obligadas a afrontar crisis que las van a transformar profundamente. Aunque la autora se muestra muy valiente al cuestionar algunos de los mitos y discursos hegemónicos sobre la maternidad en distintos momentos históricos, también recurre ocasionalmente a algunos clichés con respecto a las madres y sus hijos que pueden hacer peligrar su clasificación como textos feministas. Como alguna otra literatura sobre el tema, Ní Chonchúir se muestra ambivalente ante la cuestión de si la maternidad debiera de ser concebida como un constructo social - o institución - o, por el contrario, como un aspecto natural y consustancial a la condición de mujer. En todo caso, Mother America ofrece una visión iluminadora de los dilemas que casi 
siempre acompañan al tema de la maternidad y en contadas ocasiones realiza juicios morales con respecto a los triunfos y las derrotas de los personajes.

Palabras clave. Mother America, relatos cortos, maternidad, Nuala Ní Chonchúir, maternidades atípicas, mujeres engañadas.

There have always been mothers but motherhood was invented. Each subsequent age and society has defined it in its own terms and imposed its own restrictions and expectations on mothers. Thus motherhood has not always seemed and been the same.

Ann Dally, Inventing Motherhood

\section{Introduction: On Motherhood in Ireland}

As Dally and other theorists (Badinter, Chodorow, Forna, and Swigart, to mention but a few) have argued, although relatively young in human history - the first references in English date back to the late $16^{\text {th }}$ century -, the concept of motherhood has evolved very quickly during the last two millennia. Because it has been used by states, religious creeds, the arts, and other institutions for particular social, political, and moral purposes, it has come to signify distinct things in different locations and at different historical junctures. In Dally's words, "Motherhood has become full of uncertainty and paradox, fraught with dilemmas at all stages, arousing passion and anxiety, creating illusion and also being altered by it" (18). It is precisely the fact that motherhood has often been the object of idealization - most conspicuously during the Victorian era, but also in more recent periods - that has put a particularly severe strain on women's reproductive and nurturing faculties. ${ }^{1}$

Chodorow claims that, as any society's dominant mode of production, the mothering system is "a fundamental determining and constituting element of that society, socially constructed, subject to historical change and development, and organized in such a way that it is systematically reproduced" (8). According to this psychologist, at the time of the industrial revolution the separation between the domestic and the public sphere began to sharpen, thus producing a specific form of nuclear family that could be reduced "to women's mothering and maternal qualities and heterosexual marriage, and continuing to reproduce male dominance" (10). In this context, motherhood is rapidly institutionalized (see Rich 118-123) and becomes the prevailing ideology in most Western capitalist countries, in which the narrowly-defined and strictly-policed discourses of "good motherhood" leave little space for any other scripts that women might have envisioned (Forna 3-4). ${ }^{2}$ This picture is further complicated in the case of Ireland, in which the history of (post-)colonialism, the dominant role of the church, and, later on, the nationalist sentiment intersected to make the condition of women in general, and mothers in particular, especially subjugated. Weekes, for example, notes that the important influence of Catholic ideology and the ultraconservative familist policy of the new Irish state imposed crushing restrictions on women (100-105) and, in a similar vein, Fogarty maintains that maternal ideals of "purity, asexuality, and a self-denying devotion to others" (87) were greatly reinforced by all the imagery related to the Virgin Mary.

Moloney and Thomson have argued that one can easily discern the "foundations of Irish culture - state control of women's reproduction, and the nationalist and religious mythologies, [the] Virgin Mary and Mother Ireland - that have framed and, therefore, limited Irish women" (198). The fact that these foundations prevailed throughout the best part of the $20^{\text {th }}$ century resulted in the repression of and silence about many of the issues that were 
integral to the female experience during those long decades: marital breakdowns, unwanted pregnancies, abortion, domestic violence, and so on. Likewise, in terms of form, except for a handful of brave women writers - such as E. O'Brien or M. Lavin - who ventured beyond the frames of the local and realist aesthetics, there was hardly any imaginative experimentation trying to resist or subvert the prescribed conventions. A certain parallelism could be drawn, in fact, between what Forna has referred to as the moulds and constraints that society has historically levied on women - and more specifically on mothers - (6-9) and the rigid margins within which women writers felt compelled to move in their art (cf. Barros del Río 77). In this regard, Patten acridly complained in the mid-1990s that women's fiction in Ireland had gone through an "abnormally long adolescence" (8) in the previous decades that had often derived into a profound and undesirable sense of paralysis:

The historical attachment of female writers to confessional and autobiographical realism is a tradition, but not a necessity. Economic and sexual constraints on women still exist in Ireland, but meeting them head-on with literary restraints and conventions is essentially negative. In Ireland, there is a vested interest in producing women's writing which is stylistically transparent, reactionary, anti-intellectual, antiphilosophical, and realist to the point at which it slips easily into journalism or polemic. (15)

While one may partly agree with Patten and O'Faolain on the negative impact that "a return to the old, ordering empire" (O'Faolain 8) may have had on women's (short) fiction in Ireland, it was clear by the mid-1980s that several forces were already pushing in a different direction. On the one hand, with the consolidation of the Second Wave of Feminism in the 1970s and the revisionist work on motherhood by scholars such as Badinter (1981), Rich (1976) or Oakley (1981), the obscure reasons for the institutionalization of "good motherhood" as a social construction - and mandate - began to be ferreted out. Rich came to the conclusion that "the control of women's bodies by men" had been a historical constant and that "[t]he woman's body is the terrain on which patriarchy is erected" (56-83). On the other hand, in Ireland several other crucial socio-cultural and political transformations - joining the European Union, a loosening of the grip of the Catholic church, new progressive legislation, economic prosperity, growing immigration, etc. - were underway, which also had a significant impact on the situation of women in Irish society (see Hill 215-218). ${ }^{3}$ No doubt, these also had a direct effect on how women writers decided to represent the female (and maternal) experience in their fiction and poetry, with many of them openly recognizing their feminist leanings. In Estévez Sáa's words,

Once they have returned from that liminal space they had been forced to inhabit, Irish women writers of short stories have expressed the need of coming to terms with a realist non-stereotyped representation of Irish women's lives and experiences not subordinated to Catholic and nationalist ideologies that have traditionally colonized the image of women in Ireland. (153)

Indeed, as Chang has recently shown, a new generation of Irish women writers - Clare Boylan, Éilis Ní Dhuibhne, Mary Morrissy, and Claire Keegan, to name just a few -, who have been especially interested in the short-story form, have dug deeply into and challenged myths of female responsibility and solidarity "by unveiling paradoxes within the prescribed patriarchal gender roles and ideology" (9). Although Chang concentrates on the problems raised by the representation of sisterly relationships in her article, it shall be observed below 
that similar implications about the complexity and ambivalence of mother-son and motherdaughter relationships may be derived from the stories in the collection under analysis here.

By the time Nuala Ní Chonchúir published Mother America and other Stories in 2012, she was already fairly well known as a short story writer, since three earlier collections had already seen the public light: The Wind across the Grass (2004), To the World of Men, Welcome (2005), and Nude (2009). ${ }^{4}$ Reviewers of those collections identified and highlighted three main fortes in her short fiction. On the one hand, it was evident to them that this was the work of a poet/writer, for she used the power of her lyrical skills to create microcosms of love, life, and loss, all brimming with sensuality. On the other hand, they also stressed the incredible diversity in tone and style of her stories, which managed to capture the most magical - and catastrophic - moments in ordinary lives of, mostly, women in just a few pages. ${ }^{5}$ But perhaps what astonished reviewers the most was the poise and competence with which she dealt with themes (sexuality, troubled relationships, nudity, family secrets, etc.) that had been taboo for most Irish women writers of earlier generations. Although she has admitted in several interviews that she is by no means the first one to break the deafening silence surrounding the female experience in domestic settings and has recognized the influence of Anne Enright, Éilis Ní Dhuibhne, and Mary Morrissy on her work (MoralesLadrón, "I Write" 131), there is an honesty and urgency in her voice that makes her writing particularly real. As she explained to Morales-Ladrón, what she admired most in those writers was that "They were writing about women and about women's lives, in and out of the bedroom. They were writing sort of bold, in terms of brave, stuff" ("I Write" 131).

Certainly, those same two adjectives could be applied to Ní Chonchúir's decision to deal specifically with the theme of motherhood in her fourth collection of short stories, a topic that despite the large amounts of paper and ink devoted to it in the last four decades still seems as problematical as when Rich and Badinter were making their early ground-breaking incursions into it. DiQuinzio, for one, has remarked that feminists remain somehow divided on the topic as many still view motherhood - especially in its biological dimension - as a source of oppression, while others look at it as an important part of women's identity, "a basis of women's value as members of society" (ix). This scholar claims that the picture gets more complicated when one considers how issues of "essential motherhood" and individualism intersect - and often clash - in such a way that they "position women in a very basic double bind: essential motherhood requires mothering of women, but it represents motherhood in a way that denies mothers' and women's individualist subjectivity" (xiii). As shall be observed below, Ní Chonchúir's Mother America tries to delve into many of the dilemmas and crises that are likely to besiege women when they come face to face with their particular modes of motherhood. One of the author's primary aims in the collection is precisely to document and dissect women's place in history and society, focusing in particular on the kind of pressures they have confronted as mothers, wives, and lovers. ${ }^{6}$ Kaplan has shown how fictional representations of mothers are generally produced through the tensions between the historical and the psychoanalytical, and then organized within specific texts in terms of contradictory mother-discourses and prevailing ideologies (17-47). Mother America proves to be an invaluable asset in the sense that it allows us to see many of the aspects of motherhood that have been both revered and reviled in different contexts and circumstances, without ever passing a moral judgment on characters trapped by love, failed relationships, myths and ideals or simply accidents of life.

\section{Unusual Motherhoods}

In his mostly appreciative review of the collection in the Sunday Times, Shortall wrote that "Ní Chonchúir has risen to the challenge [of doing everything in the limited span of the short 
story], immediately arresting the reader's attention with jolting declarations, oddities and intriguingly out-of-place ideas" (Shortall). And indeed, the first few lines of the tale that opens the collection ("Peach") can be said to produce precisely that effect on the reader: "There was a pregnant woman getting drunk in the back lounge; I could see her through the hatch, from where I sat at the bar. She was drinking and crying, sitting on the red velveteen couch alone" (Mother 1). If, as the narrator explains, "We never got many women in The Cova", the presence of a gestating woman in the pub is quite stupefying to the few other customers - and to the reader, as well. Evidently, a pregnant woman swallowing large quantities of alcohol on her own in a public place would be looked upon, as Swigart and others have maintained, as "a bad mother". 7 No wonder, then, that the male narrator should consider what personal cataclysm may have driven this frail woman to such an outrageous social behavior: "Maybe, I thought, the baby's father had walked out. Maybe, like most of us, the rough magic of her childhood haunted her and she hoped for a better life for her kid. Or, maybe, she didn't want the child at all" (Mother 2). As the story moves on, the reader learns that the protagonist's, Maud Peach, reason for her depression early in the tale is none of those conjectured by the narrator. After she has grown closer to him, Maud reveals the truth about the baby boy she has recently brought into the world: "He's not my son; he belongs to my sister and her husband. They called him Max" (8). Of course, the narrator, Dominic, is deeply moved by the unbearable pain that he sees Maud is still suffering from:

... Her weeping reminded me of the lavishly grieving mothers of TV news - Muslim women shaking their hands, groaning into aprons, the dead child swaddled in some horribly ordinary floral cloth. Years of love reduced to public wailing and a small body rocked above a crowd, passing roughly from hand to hand. At least they had a process, I thought; Maud, it seemed, was left with nothing. (Mother 8)

The story dwells upon the kind of mourning that often accompanies a woman's, in this case a surrogate mother's, separation from her biological child. Maud feels betrayed by her sister and her husband because they had led her to believe she' $d$ have "A really close auntie-nephew relationship" with the boy, but now "They're gone to live three thousand miles away, to Boston, and I'll hardly ever see them. See him" (Mother 9). Dominic tries hard to empathize with Maud, especially by comparing the grieving she is going through at the moment to the one he experienced when he split up with his wife: "It's normal. I was like that after I separated from my wife; life was blurry for about two years" (Mother 9). Nevertheless, the story makes it clear that it is fairly impossible for a male mentality to try to grasp the pain and anxieties that accompany a mother's separation from her child. ${ }^{8}$ As the author concluded in an essay on "The Art of the Body", "Women are different" (127, italics in original), and it is precisely their very different approach to their bodies and the relationships they build with others through them that makes their art relevant: "Not better, not worse, but good and relevant" ("The Art" 127).

One can easily tell why "Peach", which was shortlisted for the 2012 prestigious Pushcart Prize and won the Jane Geske Award, immediately caught the readers' attention and interest. On the one hand, there are all the controversies surrounding the issue of surrogacy, which must have sparked in the readers' minds as they were learning about Maud's unexpected trial. Although Rich had already talked in the "Afterword" of her classic book about the frictions that are likely to upsurge in women's lives with them having an increasing control of their bodies but, simultaneously, also needing to maintain a certain "bond with the natural order" (285); the dire positions to which they can be brought by this conflicting double pull can only be observed in cases such as Maud's. On the other hand, the fact that Maud's excruciating story is told from the point of view of a male narrator, Dominic, who, as 
the development of the story shows, is not himself free of loss and psychic injuries, adds to the intricacies of how expectations and betrayals should be understood in the context of this special type of motherhood. The narrator's reckless swim across "the black Liffey" and his persistent apologies to Maud near the end of the tale (Mother 17) only come to confirm his failure at having properly read and handled the situation.

"Scullion" presents us with another tortured motherhood as the protagonist-narrator, Mary, a housemaid at Clongallen House, is also dispossessed of her biological son when the lady of the house - who she refers to as "Herself" (106) - loses her own baby during childbirth. The reader soon learns that s/he has been transported to a different place - a rural manor - and a fairly distant past, although no specific date or temporal markers are provided in the story. Throughout the tale, we realize that Mary, as a young servant of fourteen, is completely at the mercy of the whims and abuses of the owners of the estate house. In various ways, her body becomes the locus of what Chodorow and Rich have deemed the darkest and most unfair aspects of (re)production in conservative and capitalist modern societies, in which women are merely conceived as pieces in the reproductive machinery. In an interview with Gay, Ní Chonchúir noted that the theme of betrayal becomes central in this collection because many of the stories have "to do with power and shifts of power and loss", which "can be a great kick off point for friction in a story" (Gay).

In "Scullion", this element of friction and competition becomes apparent from the very first lines of the story: "Sometimes I want to say to her, "Your man has a better time in a short night with me than he has with you in a long week" (Mother 105). However, Mary's selfdeception about the powers that her young, blossoming body may confer to her are very shortlived and she is shaken up to her real condition when the baby boy is snatched from her just one day after his birth: "The Master lunges and grabs the baby; he pulls my son off my breast and I cry out in pain. The baby yelps in fright" (Mother 112). If the physical pains of early separation surface soon after, it is the psychological wound inflicted on the young mother that seems more distressing: "In my room, Cook holds cabbage leaves and hot compresses against my breasts; I can barely move with the pain of the engorgement. I weep into Cook's apron and she says 'There, there, Mary; all will be well.' But I know that she is vexed" (Mother 113). The story closes in an open-ended manner as Cook helps Mary to abduct her own child from the wet-nurse that is looking after him and kindly gives her all her savings so that mother and child may travel to America: "Take it, child; take it. There are boats to the New World from Queenstown. Maybe you'll go on one and be safely away.' I grip her hand and both of us weep. 'Godspeed, Mary."' (Mother 115). Ingeniously, the author decides to complete the narrative of Mary's trouble-ridden motherhood in a different tale of the collection, "My Name is William Clongallen". 9

In her interview with author Elisabeth Baines, Ní Chonchúir declared that while writing Mother America she had been particularly interested in the theme of mothers in conjunction with that of exile, mothers who are separated from their children by force or by will: "Ireland is also a country of emigrants and, lately, of immigrants. Historically, there is a good deal of sentimentality about Irish emigration (that continues to this day) and I am interested in that" (Baines). This interest becomes crystal clear in stories like "Letters", "Triangle Boy" or "Easter Snow", in which we witness how the relationships between mothers and their sons and daughters are profoundly affected - and often rattled - by geographical distance. In "Letters", an Irish mother growing older in New York City cherishes the mail she receives from her favorite son, who now lives on the West Coast: "Mattie's letter arrived on Tuesday morning and I saved it, like always, for the evening. For after my walk on Avenue of the Americas, which I take to feel like I am alive" (Mother 22). It soon transpires that Bridie, Mattie's mother, leads a dreary and solitary life in a tumultuous city that will never feel like home. In fact, other than by receiving her son's letters, Bridie 
only finds short moments of respite by visiting Vito, an Italian who owns a Diner on Washington Square, and "remembering Mattie as a boy" (Mother 23) in Ireland. Despite all the love that those memories of her son exude, it also becomes increasingly evident that Bridie entertains a deep resentment against the person who uprooted her from home:

Now there's no back yard, no fireplace, no potato pit. There are seven storeys below me and three above, I never imagined people lived in any way but our own, until Mattie brought me here. He brought me here and left me here, to go as far away again to the other coast, to a place full of Mexicans. (Mother 25)

Obviously, the story is fraught with resonances of the connection between Ireland as a metaphorical mother figure and the idealization of mothers as children's main source of nurture and protection. Still, Ní Chonchúir tries to de-sentimentalize some of these myths by showing how Irish individuals abroad may have a very different take on them. Bridie seems to still be intimately attached to her motherland and the memories she keeps of her beloved son, but the photograph she receives enclosed in the latter's letter appears to tell a very different story: "There is Mattie, moon-faced and smiling, stouter now than when he left; his arm is draped across the black wife and she is grim and thin, holding a baby across her breasts. Is this a son? My grandson?" (Mother 28). In the last couple of paragraphs of the narrative, the reader realizes that illiteracy keeps Bridie from understanding the contents of her son's letters, but her reaction to the picture she has just received speaks plainly of her degree of involvement in his current life: "I take up the scissors and cut Mattie from the picture. Throwing the other bit of the photograph out of the window, I bend and kiss Mattie's happy face. Next Tuesday I will show Vito a picture of my son" (Mother 28). In her introduction to the volume Irish Women Writers and the Modern Short Story, D'hoker claims that female writers such as Enright and Donoghue are trying to rewrite history by using techniques that "seek to question received views and dominant discourses about women ... and about emigration" (18). Although clearly not as metafictional and postmodern in narrative technique as the aforementioned authors, Ní Chonchúir shares with them an interest in revisiting and revising the kind of tensions and gendered hierarchies that frequently inform traditional plots about these themes (cf. Fenton).

In the title story of the collection, "Mother America", a male narrator, who lost his mother to cancer not long before, relates his strange meeting with an elderly, Americanlooking woman who claims to be his "Guardian Angel" (Mother 40) a few miles outside of Cork city. The mysterious and conspicuously pious woman picks him up on the road and, after a strained conversation, eventually manages to convince the narrator to tell her about his "mom". With great effort, Chris explains how he abandoned her during the last few days of her life because he could not bear to see her suffering that way: "The pains she had made sort of dents all over her face.' I pointed to my forehead and cheeks, then let my hands fall" (Mother 40-41). Although the narrator phoned her and tried to say "I love you" to her several times, the words would choke him and he could barely whisper them, so he is not quite sure whether she heard him. But the old lady comforts him by saying that "She heard you, Chris. She forgives you and she loves you" (Mother 41). The story wraps up with the brash narrator sobbing profusely and the woman driver exhorting him to leave her car at once, but not before she reveals to him that "They call me Mother America" (Mother 41). Although the tale is full of ironic twists and parody, it would be rather short-sighted not to realize that important liminal messages are being thrown in on alternative modes of motherhood, the topic of human mobility, and the guilty feelings and sense of lost opportunities that often plague mother-son relationships. ${ }^{10}$ 


\section{Betrayed wives}

If the variety and complexity of motherhoods in Ní Chonchúir's collection has been fairly well attested in the previous section, it will be seen in this part that, on the contrary, the portrayal of marital relationships may turn out to be rather repetitive and, somehow, dispiriting. Of course, love and conjugal relations are going to be deeply influenced by the presence of children in the family, but one would expect the outcomes of those relationships to be also as tangled and multifarious as the mother-child ones. In fact, some classic short story writers such as K. Mansfield and M. Lavin already explored in their narratives the intricacies of marital relations and their diverse effects on female subjectivities, ${ }^{11}$ which rarely responded to the idealized family tenets of the past in Ireland. D'hoker has claimed that "the short fiction of Irish women writers is abundantly concerned with questions of relationality and connection" (7) and that, more often than not, those relations reveal a dysfunctional, imperfect, and even destructive nature (see also Morales-Ladrón "Portraits"). In Mother America, however, it will be noticed that while mothers may be driven to do the most inordinate things regarding their children - "Scullion" and "Queen of Tattoo" are excellent examples of this -, the same thing could not be argued concerning their behaviors towards their husbands. Of course, some of the classics in motherhood literature (Badinter, Dally or Oakley) are very intent on showing precisely how society compels mothers to do things for their progeny that they would never think of doing for anyone else - not even their husbands or life-long partners. Mother America proves a bit disappointing in this regard - and this may well be an understatement-because the wives' responses to their men's betrayals and deceptions rarely show the kind of nerve and determination that they exhibit in other aspects of their lives. In her review of the collection, Shortall has gone so far as to speak of a depressingly "resigned ethos" permeating the volume because "no matter how diverse their personalities, the women accept the betrayals of men" (Shortall). ${ }^{12}$ As will be observed below, sometimes the wives' reactions to their husbands' disloyalties are closely connected to their responsibilities as mothers, but even in those instances the reader has the impression that the main characters are deceiving both themselves and their offspring.

In "When I Go Down, Go Down with Me", we hear the story of Máire, a middle-aged, married woman with two teenage kids, who has learnt that her husband is having an affair with a "girl" of twenty-six. In the opening scene, Máire is with her husband in bed, but she is convinced that he is fast asleep and that he believes himself to be somewhere else: "To him, at this moment, Máire's body is the girl's body; fresh, plump and yielding. She witnesses a flash of them together, the girl acrobatic despite her heft, straddling her husband and jigging. Jigjig-jig" (Mother 53). Máire has preferred to keep her husband's romantic adventure from his son and daughter because she thinks that there is still hope that her man might return to her. Nevertheless, the secret proves to be too weighty and she finally decides to tell her sister, Tríona, about it: “'It's all hush-fucking-hush, of course,' Máire says. 'Until he decides what he's going to do"' (Mother 57). Yet, Máire knows that her husband's affections for the girl are more than a passing craze and she is also conscious of her disadvantages as a seasoned woman of fifty: "Máire has found herself, lately, jealous of young people. It is not that she is old - fifty is not old nowadays - but she feels grumpy about the accomplishments of the younger women she sees, about their confidence" (59, italics in original).

The story reaches a crisis when Brian, Máire's eldest and favorite child, returns home one day completely out of himself saying that he saw his Dad in Bray: "He was with someone. He was kissing the fucking face off her, Mam, in broad daylight. On the prom!'” (Mother 61). What seems to affect the protagonist most is not that her spouse has been caught with his lover by his own son, but rather where this encounter had taken place: "This time her husband has poked a hole in the sacred memories of her heart. They had spent their 
honeymoon in Bray; two late bloomers giving love a go. The place had a lunar pull on them it was where they went, in sickness and in health, for anniversaries, for birthdays, and on outings with the children" (Mother 61). Although Máire recalls that when they married they had sworn "that if one of them wanted out, the other would let them go easy" (Mother 62), she knows that she cannot fulfill that promise and tells herself that she will never "let him go at all". On second thoughts, however, alone in her kitchen later on, she reflects a bit more deeply on the wisdom of that earlier decision:

How do you right a toppled marriage? Get it back on its feet and teetering forwards like a splay-legged foal, newborn and unsure. Maybe, Máire thinks, the legs of this marriage are too gnarled and it will never be steady again. She uncorks the wine and pours. Around her the house sighs and creaks, then sighs again, answering itself back. (Mother 62)

These final lines may suggest that Máire is ready now to take more dramatic steps concerning her husband's infidelity, but the reader cannot be sure if she will gather the courage to do so when she confronts her children and the man himself. After all, we know from earlier passages in the tale that she is very resistant to any new fears threatening her marriage: "Sweep and pile; a hillock of crumbs to arrange and re-arrange; it could go on for a long time. We'll be grand, grand, grand, she thinks. Of course we will" (Mother 60). ${ }^{13}$ In a number of interviews, Ní Chonchúir has pointed out that she sees herself as part of "a new wave of women writers" in Ireland (Morales-Ladrón, "I Write" 136) and her work as political, as she approaches issues from a "feminist" point of view (Fenton; Gay). Nevertheless, stories like "Moon Hill", "By Ballytrasna" or "From Jesus to the Moon" showcase wives - and widows trapped in marriages and family secrets that somehow constrain their pragmatic choices in ways that make readers feel that they become pathetic figures. Sometimes, they may seek assistance from their children - if they happen to be old enough - but, sadly, in most instances they are not quite understood by them.

Curiously, it is in the two or three historical fictions appearing in the collection wherein the women appear more able to get back the reins of their lives and take them where they wish to go. In a conversation with Lynch, Ní Chonchúir remarked that she obtains great pleasure from "reimagining other time periods" (Lynch) and the lives of women in other historical contexts, especially if they are artists. This is the case of "The Egg Pyramid", a second-person story in which the well-known Mexican artist Frida Kahlo is invited to consider what she can do about her husband's adultery with her own sister:

There are things you can do when your husband sleeps with your sister. You can sit in your studio and imagine them together, the toad and the mouse. ... But he is your toad and she is your mouse - your Diego and your Cristina - so you drown those thoughts because they bring more tears than blood-letting. (Mother 19)

The tale quickly moves through the list of things that the protagonist could do in order to "compensate" or, at least, to relieve the pain of Diego Rivera's betrayal. However, she also knows that because of her husband's character, the fact that she has already lost three babies, "the itches to be scratched on both sides" (Mother 20), and, particularly, because of her passion for him, these battles are probably lost: "Your husband is an accident that happened to you but he is also your north and south. And, because you love him more than your own skin, you can try to accept and you can try to forgive" (Mother 20). Fortunately, a last resort to deal with her deep pain and passion is available to Frida in her art: 
But, when your sister sleeps with your husband, it is like balancing a pyramid of eggs on a glass platter on the top of your head. You dare not move much for fear of what might happen. The best thing that you can do is to take your brush in one hand, your palette in the other, and sit at your easel and paint. Yes, you can paint". (Mother 2021)

More tragic is the situation of Assia Wevill, poet Ted Hughes' lover for seven years, in the tale "Cri de Coeur". Assia also recounts in the first person the up and downs of that relationship, focusing primarily on the periods of time she spent with the artist on the west coast of Ireland. Like many of the other tales, "Cri de Coeur" begins with a really shocking scene. Assia brings her four-year-old daughter, Shura, to the kitchen of their flat, where she pretends they are going to be playing "a new game" (Mother 42). After giving her daughter a "fairy potion", Assia places her on a cozy mattress on the kitchen floor and "I go to the stove and turn each gas jet to full, then I lie beside her" (Mother 43). The rest of the circular story relates, from the protagonist's point of view, the events that brought her to such an outrageous deed. At first, escaping to Ireland seems to have a very positive effect on their extramarital relationship, since the poet becomes more productive "And Sylvia's head did not lie on the pillow between us as it always did at home in England" (Mother 43). But as time goes by, it becomes increasingly clear that the poet is treating the protagonist as a convenient accessory to his life and his absences grow longer and longer: "I wait for Ted to come to us. But he doesn't come. On the telephone we snipe; or he doesn't talk at all and I rant" (Mother 50). Although Assia takes pride in her accomplishments as a mother and her innovative work in the advertising business, she also realizes that she will never manage to occupy the place of his earlier wife in the poet's heart: ${ }^{14}$

Back in Ireland I shone; I managed things; I kept the house, I got soiled under my nails. The children behaved and we were a family, Ted's little tribe. Still I could never match she who was everything: mother, homemaker, writer, muse. Sylvia floated over our heads all the time we were there, a silent balloon. In Connemara we were waiting and we didn't even know it. (Mother 51)

Feeling completely "displaced and unplaceable" in the poet's life, she knows that she does not want to be just "a prop" in it: "I won't have it. I know what I deserve and what Shura does too, but we don't get what we deserve. We endure. Then we die" (Mother 52). The story closes with a repetition of the same scene that opened it, but now the reader knows what kind of duplicities and grieves could bring a young, bright woman - and mother - to such a calamitous end.

\section{Closing remarks}

At the outset of her book on The Representation of Motherhood, Kaplan admitted that her "contradictory relationships" with her mother and her daughter directly fuelled her academic work: "I wanted to find out how mothers are constructed in patriarchy on the assumption that such research would not only contribute to knowledge but also enlighten my own struggles, both as a daughter and a mother" (ix). The fact that Nuala Ní Chonchúir dedicates Mother America "For my mother, Nuala, and the ones I mother - Cúan, Finn and Juno" likewise indicates that a great deal of personal and emotional investment went into the collection. She has recognized in conversations that, besides the traveling she undertook while composing the stories, she was also going through a difficult period in her life as she divorced and remarried, and all the while she had to attend to the needs of her three children (Lynch). Undoubtedly, 
going through all these experiences must have contributed definitely to her interest - one would dare say absorption - in the themes of difficult love relationships and the tribulations of the close connection existing between mothers and their children.

As the first part of this article has shown, one of the main strengths of Ní Chonchúir's collection is that it looks at motherhood from very diverse points of view, in very different places (Dublin, Ballytrasna, Galway, Paris, New York, Rome, etc.), and coloring it with mixed "shades of dark and light" (O'Callaghan). While tales like "Triangle Boy" and "Moongazer" shock us with the huge loneliness that can emerge in mothers and sons due to distance from the motherland or infertility, others like "Scullion" or "Easter Snow" finish on a more positive note. In "Easter Snow", for instance, a young, exiled Irish mother-to-be is comforted by the sound of her yet-unborn baby in hospital after she has had a silly accident on the streets of New York: "Our child is there, a pulsing egg; he sends out his slow, sonic whirr to us through the blizzard that surrounds him. We hear it and catch it and take it home with us through the snow" (Mother 118). The author has admitted in some interviews that she never knows what will happen in a story when she begins to write it; she just starts out and lets the characters' moves take her wherever they want - or are pushed by circumstance - to go (see Baines). This way of writing allows Ní Chonchúir to end up with a set of stories that, while plunging into connected themes, still show great variety in terms of voice, setting, gender perspective, lightness or darkness, and denouements. Something that should have been made clear by the analysis of a few "unusual motherhoods" in Mother America above is that, as Howorth has recently explained, "... for all the communal aspects of bearing and raising children, for all the prescriptions we follow on the path of shaping another human, motherhood is a uniquely individual experience" (Howorth) and, as such, full of gentle joys but also cruel defeats.

Despite all the praise bestowed on the collection by reviewers and other authors on account of its uncompromising representation of women's experience in different historical periods and the graceful and measured language with which those lives are portrayed, it has also been noted that there are aspects of the volume that should be more severely assessed. For one thing, readers - and especially female readers - are likely to feel a bit upset with some of the contemporary wives and mothers depicted in the collection who seem incapable of coming up with commensurate reactions to their husbands' unfair treatment and their children's heavy demands. The protagonists of "Moon Hill" and "Queen of Tattoo" would be a case in point as they see themselves obliged to accept situations that no woman should be brought into by their loved ones. In the latter one, for example, Lydia, the tattoo artist of the title, is troubled by all sorts of horrifying images while tattooing her son Clyde, a rapist, to protect him from other criminals: "Her mind fills with serpents. She thinks of her Bible, of the prince who was like a wolf devouring prey 'to shed blood, and to destroy souls, to get dishonest gain"" (Mother 159). Lydia ends up - despite her reticence - needling those hideous pictures into her son's body and, indirectly, contributing to his death soon after. As explained throughout the article, wives and mothers of adult children make concessions for their spouses and grown-up sons and daughters that force them to overlook some of their most deep-rooted principles and convictions. If as suggested earlier on in the article, a woman artist should attempt to keep a balance between visions of motherhood that recognize free choice and subjectivity and those others that stress feminine sensuality and maternal instinct, it is always important to make sure that neither of the two approaches ultimately gets the upper hand. In Mother America, the reader has the impression that the author falls into a number of clichés such as female divisiveness, women's passion, maternal favoritism, etc. -, often represented by means of myth and symbol (moon, water, etc.), that compounded with more factual "betrayals of the body" (Gay) - such as aging, infertility, ugliness, etc. - may cause that unstable balance to be upset. 


\section{Notes}

${ }^{1}$ For a fairly thorough historical overview of the construction of the "maternal instinct", see the first two chapters of Badinter's The Myth of Motherhood.

${ }^{2}$ In Forna's view, the motherhood myth responds to the ideal of the "Perfect Mother" who must be completely devoted to her children (and husband), and is characterized by her softness, intimacy, and nurturing qualities.

${ }^{3}$ Evidently, these transformations did not reach all areas of the country at the same time and with the same force. Furthermore, one needs to keep in mind the heterogeneity of the reception that those changes had on different segments of the population.

${ }^{4}$ Nude, in particular, received very favorable reviews in the major newspapers in Ireland and the United Kingdom.

5 The elegant simplicity of her use of language and the pitch-perfect and economical narrative voices have become some of the trademarks of her fiction.

${ }^{6}$ In an article in Revista Anglo Saxonica, the author recognized her indebtedness with writers such as Anne Enright, Emma Donoghue, Claire Keegan or Éilis Ní Dhuibhne, from whom she learnt of the importance of tackling women's issues and of doing it by using the right type of language ("Pathways" 133).

${ }^{7}$ Forna has also written about how societies tend to make "deviant mothers" feel guilty and even punish them in Chapter 6 of her book, "Persecuting Mothers and the Law". One should also refer here to Foucault's views in his History of Sexuality (1976).

8 Sammy Lee considers in her book Motherhood in the $21^{\text {st }}$ Century some of the problems that fertility treatments, family/work reconciliation and surrogacy may cause among mothers in our era.

${ }^{9}$ Ní Chonchúir has referred in a couple of interviews to the importance of these connections between different stories (Baines; Foyle), which according to the author provide the collection with higher levels of cohesiveness.

${ }^{10}$ It is interesting to notice that the two or three stories in the collection in which Ní Chonchúir takes an unexpected turn towards the surreal are very intelligently inserted among the more ponderous, and generally darker, realistic and historical fictions.

${ }^{11}$ See, for example, some of the stories in Mansfield's The Doves' Nest and Other Stories (1923) or Lavin's Happiness and Other Stories (1972).

12 O'Riordan review of the book also points in a similar direction, with some of the plots becoming "predictable".

${ }^{13}$ For an eye-opening discussion on the kind of cultural contradictions that contemporary mothers are sometimes caught in, see Hays, especially Chapter 5, which deals with what she calls "intensive mothering" (91 and ff.).

${ }^{14}$ Assia Wevill's relationship with Ted Hughes brings to mind so many others in which the individuality and the will of a bright woman are utterly undermined by her partner. Asher has described in Shattered - see especially Chapter 5 - this type of process.

\section{Works Cited}

Asher, Rebecca. Shattered: Modern Motherhood and the Illusion of Equality. London: Harvill Press, 2011.

Badinter, Elisabeth. The Myth of Motherhood: A Historical View of the Maternal Instinct. London: Souvenir Press, 1981.

Baines, Elisabeth. "An Interview with Nuala Ní Chonchúir about her New Collection of Short Stories”. Elisabeth Baines' Blog. 6 August 2012. 15 June 2015. http://elizabethbaines.blogspot.com.es/2012/08/an-interview-with-nuala-nichonchuir.html

Barros del Río, María A. Metáforas de su tierra: Breve historia de las mujeres irlandesas. Oviedo: Septem, 2004.

Chang, Ann Wan-lih. "Psyche's Sisters: Ambivalence of Sisterhood in Twentieth-century Irish Women's Short Stories". Estudios Irlandeses 8 (2013): 1-11. 
Chodorow, Nancy J. The Reproduction of Mothering: Psychoanalysis and the Sociology of Gender. Berkeley, L.A. and London: University of California Press, 1978.

Dally, Ann. Inventing Motherhood: The Consequences of an Ideal. London: Burnett Books, 1982.

D'hoker, Elke. Irish Women Writers and the Modern Short Story. London: Palgrave Macmillan, 2016.

DiQuinzio, Patrice. The Impossibility of Motherhood: Feminism, Individualism, and the Problem of Mothering. New York and Oxon: Routledge, 1999.

Estévez Sáa, Margarita. "The Seanchai': Short Fiction by Irish Women Writers from the Republic". Postcolonial and Gender Perspectives in Irish Studies. Ed. Marisol Morales Ladrón. A Coruña: Netbiblo, 2007. 139-154.

Fenton, Rachel. "A Mother Land". Snow Like Thought. 8 July 2012. 15 June 2015. http://snowlikethought.blogspot.com.es/2012/07/mother-land.html

Fogarty, Anne. "Mother-Daughter Relationships in Contemporary Irish Fiction". Writing Mothers and Daughters: Renegotiating the Mother in Western European Narratives by Women. Ed. Adalgisa Giorgio. Oxford: Berghahn Books, 2002. 85-118.

Forna, Aminatta. Mother of all Myths: How Society Moulds and Constrains Mothers. London: Harper Collins, 1999.

Foyle, Órfhlaith. "Review and Interview with Nuala Ní Chonchúir". Órfhlaith Foyle's blog. 4 June 2012. 15 June 2015. http://orfhlaithfoyle.blogspot.com.es/2012/06/motheramerica-by-nuala-ni-chonchuir.html

Gay, Roxane. "In Conversation with Nuala Ní Chonchúir". Pank Magazine. 13 August 2012. 15 June 2015. https://pankmagazine.com/2012/08/13/in-conversation-with-nuala-nichonchuir

Hays, Sharon. The Cultural Contradictions of Motherhood. New Haven: Yale University Press, 1996.

Hill, Myrtle. Women in Ireland: A Century of Change. Belfast: Blackstaff Press, 2003.

Hively, Zach. "Review of Mother America, by Nuala Ní Chonchúir". Alone at the Microphone. $16 \quad$ July $2012 . \quad 15 \quad$ June 2015. http://znhively.blogspot.com.es/2012/07/mother-america-by-nuala-ni-chonchuir.html

Howorth, Claire. "Motherhood Is Hard to Get Wrong. So Why Do So Many Moms Feel so Bad about Themselves". Time Magazine. 19 October 2017. 1 November 2017. http://time.com/4989068/motherhood-is-hard-to-get-wrong/

Kaplan, E. Ann. Motherhood and Representation: The Mother in Popular Culture and Melodrama. New York: Routledge, 1992.

Lee, Sammy. Motherhood in the 21 $1^{\text {st }}$ Century: A Stock Take. London: Murray Print, 2011.

Lynch, Éadaoín. "Mother America-Nuala Ni Chonchuir". Writing.ie: Interviews. 5 June 2012. 15 June 2015. https://www.writing.ie/interviews/mother-america-nuala-nichonchuir/

Moloney, Caitriona and Helen Thomson. Irish Women Writers: Speak Out Voices from the Field. Syracuse, NY: Syracuse UP, 2003.

Morales-Ladrón, Marisol. "II Write Short-Short Stories while I am Writing a Novel": Interview with Nuala NíChonchúir". Estudios Irlandeses 9 (2014): 128-136. . "Portraits of Dysfunction in Contemporary Irish Women's Narratives: Confined to the Cell, Lost to Memory". Family and Dysfunction in Contemporary Irish Narrative and Film. Ed. Marisol Morales-Ladrón. Oxford: Peter Lang, 2016. 29-83.

Ní Chonchúir, Nuala. The Wind across the Grass. Arlen: House, 2004.

- To the World of Men, Welcome. Arlen: House, 2005. . Nude. London: Salt, 2009. 
. "The Art of the Body: Poem as Female Self-Portrait". The Watchful Heart: A New Generation of Irish Poets, Poems and Essays. Ed. Joan McBreen. Cliffs of Moher: Salmon Poetry, 2009b.

. "Pathways into the Irish Short Story". Revista Anglo Saxonica III.5 (2013): 127-138.

Oakley, Ann. From Here to Maternity: Becoming a Mother. Bungay: Pelican Books Ltd., 1981.

O'Callaghan, Billy. "Stories Span the Globe”. The Irish Examiner. 4 June 2012. 15 June 2015. http://www.irishexaminer.com/archives/2012/0804/features/stories-span-theglobe-202995.html

O'Faolain, Julia. "The Furies of Irish Fiction". The Richmond Review. Special Issue 1997. 12 June 2007. http://richmondreview.co.uk/library/ofaola01.html. 1-9

O’Riordan, Valerie. “'Dark Terrain'-Mother America by Nuala Ní Chonchúir”. Bookmunch. 27 August 2012. 15 June 2015. https://bookmunch.wordpress.com/2012/08/27/darkterrain-mother-america-by-nuala-ni-chonchuir/

Patten, Eve. "Women and Fiction 1985-1990". Krino 1986-1996: An Anthology of Modern Irish Writing. Ed. Gerald Dawe and Jonathan Williams. Dublin: Gill \& Macmillan, 1996.

Rich, Adrienne. Of Woman Born: Motherhood as Experience and Institution. New York: W.W. Norton, 1986 (1976).

Shortall, Eithne. "Short, Sharp and Shocking". Sunday Times. 29 July 2012. 15 June 2015. https://www.thetimes.co.uk/article/fiction-short-sharp-and-shocking-zc3k8t8c5z2

Swigart, Jane. The Myth of the Bad Mother: The Emotional Realities of Mothering. New York: Doubleday, 1991.

Weekes, Ann Owens. "Figuring the Mother in Contemporary Irish Fiction". Contemporary Irish Fiction: Themes, Tropes, Theories. Ed. Liam Harte and Michael Parker. London: Macmillan, 2000. 100-124.

Received: 6 November 2017 Revised version accepted: 15 February 2018

Aitor Ibarrola-Armendariz teaches courses in migrant fiction, ethnic relations, film adaptation and academic writing in the Modern Languages and Basque Studies Dept. of the University of Deusto, Bilbao. He has published articles and edited volumes [Fiction and Ethnicity (1995), Entre dos mundos (2004), Migrations in a Global Context (2007), On the Move in English Studies (2016)] on minority and immigrant narratives and processes of cultural hybridisation. He is currently preparing a book on trauma and ethnicity and is also involved in two projects on diasporic identities and the American West.

aitor.ibarrola@deusto.es 